\title{
Research on Reforming of Teaching System of Computer Common Course
}

\author{
Hansong Dai ${ }^{1, a}$, Fengjuan Guo ${ }^{1, b}$ \\ ${ }^{1}$ Sicence \& Technology College, North China Electric Power ; \\ adaihansong@126.com, bgfj0917@126.com
}

Keywords: Computer common source, Teaching system, Reform thinking.

\begin{abstract}
With the development of computer technology and network technology, the reform of computer common source teaching become more and more important and urgent in the training of compound talents with computer professional abilities. So that each student can be taught in accordance with their aptitude and explore their maximum potential. This paper analysis the current teaching system of computer common course and suggests countermeasures against the deficiencies of current system, and design appropriate, effective education evaluation system.
\end{abstract}

\section{Introduction}

The increasing rapid pace of development of science and technology makes the employers of many fields increasingly concern about the employees' ability of computer application capacities and ability of operating application software. However, at present, there are some disadvantages in the computer common course teaching system, so the students' ability of computer skills and innovative ability is generally inadequate with the demand of society. In order to adapt the changing situation, the curriculum designers and teachers must carry out in-depth exploration and practice in the teaching contents and teaching methods, keep the closely integration in classroom teaching and social needs, promote the reform and development of computer common course in colleges, and cultivate high-quality talents to meet the actual needs of the society.

\section{Characteristics of Computer Common Course}

\subsection{Diversity.}

At first, the diversity of computer common course is most reflected in the diversity of teaching content. Because of the wide application of electronic computers in daily life and work, The range of computer application has not limited to typing, table processing and other simple text needs, It's more and more important for everyone to master some basic network technology, anti-virus technology, computer and network maintenance technology and software design technology.

With the powerful function of computer software, scientific analysis and calculation software play an important role in big data analyzing and researching. So it's important to integrate the use of tool software, programming environment and data analysis software into the teaching content of computer common courses.

The second aspects of the diversity of computer common courses are reflected in the professional diversity. The use of computer technology is becoming more and more professional in different ways. So it's inappropriate to use the same curriculum course system for students of different majors

The third aspects of the diversity of computer common courses is reflected in the diversity of students' knowledge base of computer science, In addition, the different personalized needs of computer learning of students should not be ignored.

\subsection{Hierarchy.}

Hierarchical is one of the characteristics of computer common courses. Different courses should be based on different computer cognitions of students. Therefore, it's necessary to deep think and design the teaching system in order to carry on the teaching of the whole computer common course step by step. The American psychologist Ausubel's learning theory, also known as "cognitive assimilation 
learning theory" said, the students should be meaningful reception learning, and that means learning is the process of establishing the connection between with new knowledge and the existing structure of cognitive of the students. He also encourage the students to learn the unknown knowledge using their existing knowledge. Teaching the student without knowledge foundation is unrealistic, and also irresponsible. Emphasizing the frontier and advanced of the content of courses excessively, ignoring the existing cognitive structure of students, will lead to the failure of learning.

Therefore, we must pay attention to the characteristics of hierarchy in the design of the teaching system of the computer common courses, we must follow the principle of advance gradually in due order.

\subsection{Continuity.}

The computer common course should be a complete teaching system which runs through the whole university education, it should not simply terminate in the basic teaching stage.

The students' professional knowledge is deepening together with their cognition of computers. And some students has the need to use some professional computer application software. Therefore, it is very necessary and important to design and implement the teaching system of computer common courses in a reasonable and comprehensive way.

\section{Reform of computer common course}

\subsection{Reconstruction of teaching materials and update teaching content.}

As an important part of computer common courses teaching, the teaching material is directly related to teachers' teaching effect and students' learning effect. With students' ability improving, how to adjust the course structure to accommodate with the rapid development of computer technology is getting more and more important, so the corresponding teaching material should be update to keep pace with the times.

\subsection{Develop the teaching content of adaptive development.}

At present, there is no much up-to-date technology and theory knowledge in the existing basic computer common courses system, for example, in the course of information technology foundation. The teacher mainly introduce the knowledge of micro machine operating system to the students. So the students' understanding of the computer is still of the microcomputer and windows operating system. So we can introduce computers in different fields to students, such as super computers, mainframes, smartphones and their operating systems.

At the same time, the content of the practice session of the course of information technology foundation is still stuck in the daily operation of the windows system, according to the survey of the students, teacher can introduce appropriate group strategy, registry, BIOS and other senior application content to the students.

\subsection{Adopt appropriate teaching methods.}

We should abandon the previous single didactic model, enhance the practical ability of students. For example, in the course of hardware composing, using the obsolete machines in computer lab, divide students into groups to study on the hardware, enhance students' cognitive ability and practical ability. And in the course of programming, students are divided into groups to discuss some problems based on deformed typical algorithm, and resolved some practical problems based on the algorithm.

\section{Practice on computer common course}

According to the characteristics of the computer common course, a reform program was developed. The teaching system of the computer common course runs through the course of different majors, and penetrates into their professional teaching.

\subsection{Classified Teaching.}

Classify all non-computer majors into categories and make specific arrangements for the course content and teaching plan that can be combined with the professional teaching system. 
The majors are divided into five categories: science, arts, engineering, financial management, art design. Different computer common source are prepared for the different categories. For example, the teaching of computer software for scientific computing and numerical analysis such as SPSS and Matlab are arranged for the students of science, the teaching of computer software for network database and network technology security that closely related to modern business operations are arranged for the students of financial management. The detail arrangement are shown as the following table.

Table 1 Computer common courses of non-computer majors in different categories

\begin{tabular}{|c|c|c|c|c|c|c|c|}
\hline Categoriy & Term & Credit & Science & Arts & Engineering & $\begin{array}{c}\text { Financial } \\
\text { management }\end{array}$ & Art design \\
\hline \multirow{3}{*}{$\begin{array}{l}\text { Computer } \\
\text { Culture }\end{array}$} & \multirow{3}{*}{1} & 0.5 & \multicolumn{5}{|c|}{$\begin{array}{l}\text { Module 1: Basic knowledge of computer, operating system and its } \\
\text { application }\end{array}$} \\
\hline & & 0.5 & \multicolumn{5}{|c|}{ Module 2: Office software applications: Word, Excel } \\
\hline & & 0.5 & \multicolumn{5}{|c|}{$\begin{array}{l}\text { Module 3: PowerPoint, Basic knowledge and application of network } \\
\text { technology }\end{array}$} \\
\hline \multirow{4}{*}{$\begin{array}{l}\text { Computer } \\
\text { Technology } \\
\text { Electives At } \\
\text { least } 2\end{array}$} & \multirow[t]{2}{*}{2} & 1 & \multirow{2}{*}{$\begin{array}{c}\text { C++ } \\
\text { Program } \\
\text { Design } 1\end{array}$} & Web design & $\begin{array}{c}\mathrm{C}++ \\
\text { program } \\
\text { Design }\end{array}$ & VFP & $\begin{array}{l}\text { Graphic } \\
\text { design }\end{array}$ \\
\hline & & 1 & & Digit office & $\begin{array}{l}\text { assembly } \\
\text { language }\end{array}$ & VB & FLASH \\
\hline & \multirow{2}{*}{3} & 1 & \multirow{2}{*}{$\begin{array}{c}\text { C++ } \\
\text { Program } \\
\text { Design } 2\end{array}$} & $\begin{array}{l}\text { multimedia } \\
\text { technology }\end{array}$ & $\begin{array}{l}\text { Electronic } \\
\text { circuit } \\
\text { design }\end{array}$ & $\begin{array}{l}\text { network } \\
\text { database }\end{array}$ & $\begin{array}{l}\text { Static web } \\
\text { design }\end{array}$ \\
\hline & & 1 & & $\begin{array}{c}\text { Dynamic } \\
\text { web design }\end{array}$ & $\begin{array}{l}\text { Computer } \\
\text { maintenance }\end{array}$ & $\begin{array}{l}\text { Computer } \\
\text { maintenance }\end{array}$ & $\begin{array}{c}\mathrm{VB} \\
\text { program } \\
\text { design }\end{array}$ \\
\hline \multirow{4}{*}{$\begin{array}{l}\text { Computer } \\
\text { Application } \\
\text { Electives At } \\
\text { least } 1\end{array}$} & 4 & 1 & \multirow{4}{*}{$\begin{array}{c}\text { Numerical } \\
\text { Analysis } \\
\text { and } \\
\text { Graphics } \\
\text { Processing }\end{array}$} & $\begin{array}{c}\text { Computer } \\
\text { maintenance } \\
\text { and network } \\
\text { maintenance }\end{array}$ & $\begin{array}{l}\text { Interface } \\
\text { technology }\end{array}$ & $\begin{array}{l}\text { network } \\
\text { maintenance }\end{array}$ & $\begin{array}{l}\text { Animation } \\
\text { design }\end{array}$ \\
\hline & 5 & 1 & & $\begin{array}{l}\text { network } \\
\text { security }\end{array}$ & $\begin{array}{l}\text { Embedded } \\
\text { system }\end{array}$ & $\begin{array}{l}\text { network } \\
\text { security }\end{array}$ & $\begin{array}{c}\text { Dynamic } \\
\text { web } \\
\text { design } \\
\end{array}$ \\
\hline & 6 & 1 & & & $\begin{array}{l}\text { Simulation } \\
\text { technology }\end{array}$ & & \\
\hline & 7 & 1 & & & $\begin{array}{l}\text { Numerical } \\
\text { Analysis } \\
\text { and } \\
\text { Graphics } \\
\text { Processing }\end{array}$ & & \\
\hline
\end{tabular}

\subsection{Classification and sub module teaching.}

The new students will be tested for their computer knowledge and be divided into different degrees. Each degrees has the different difficulties of teaching content. In the teaching plan, the course will be divided into several modules, students complete a module and pass the examination for the module and get the corresponding credits. We use flexible teaching management and assessment methods, the credit management information system and the necessary machine test platform, and it's not necessary for the students to take the examination at the end of term, we encourage students to learning in advance and autonomous. Students who have a good foundation can make an early examination at the beginning of the sub module learning, those who pass the examination can avoid the module of the teaching process, otherwise it's still necessary for them to carry out the appropriate learning process. 


\subsection{Stage and Multi-point teaching.}

According to the characteristics of multi-level and continuity in the teaching of computer common course, it is necessary to infiltrate the computer basic teaching into the whole university life with multi-layers, multi-points. At first, the old teaching plan that common computer teaching only in the first and the second grade of university should be broken, all modules of common computer courses teaching are distributed in the entire four years of teaching plan, the multi-point teaching mode are made to make students' computer skills improved together with their professional knowledge. Therefore, the computer common courses are divided into three stages, namely: computer culture, computer technology and computer application. For the different major categories, we pay more attention to the professional characteristics of the basic courses of computer culture in the teaching plan and teaching syllabus.

\subsection{Flexible teaching.}

The establishment of the computer common course should take into account the students' own requirements, giving students the freedom to select courses.

There are 2-4 courses for students to choose and only the minimum credit value of computer public course are required. The class time and content of all courses, the available time of the open laboratory are announced to the students. Under the above conditions, flexible teaching process can be realized. Using punch machine, online homework and other high level and advanced teaching management method, flexible management of students' teaching process can be achieved.

\section{Summary}

The implementation of computer common course education reform has achieved good effect of teaching. As a result, the learning enthusiasm and initiative of student is greatly increased, the ability of using the computer software enhancement, the understanding of basic theory more profound, the independent thinking ability to plan, team consciousness and the ability to overcome difficulties have been enhances.

\section{Acknowledgements}

This work was supported by the science foundation of North China Electric Power University (104052).

\section{References}

[1] Anguo Zhou, On the teaching of college computer courses from the perspective of information literacy education, Computer Era, 12 (2006) 68-69.

[2] Xinghua Cui, Reform of teaching method of computer common course, Journal of jilin province economic management cadre college, 6 (2013) 70-72.

[3] Siqinqimuge, Analysis on the teaching of computer common course in our college, Journal of Chifeng college, 5 (2006) 48-49.

[4] Xia Jinghui, The reform of curriculum assessment methods and kills applied in undergraduate teaching, Journal of Southwestern Normal University, 6 (2013) 23-27. 